\title{
Resistence Status of Aedes Aegypti Larvae Against Temephos in Gunungpati Subdistrict, Semarang
}

\author{
$1^{\text {st }}$ Widya Hary Cahyati \\ Public Health Science Department \\ Faculty of Sports Sciences \\ Universitas Negeri Semarang \\ Semarang, Indonesia \\ widyahary27@mail.unnes.ac.id
}

\author{
$2^{\text {nd }}$ Nur Siyam \\ Public Health Science Department \\ Faculty of Sports Sciences \\ Universitas Negeri Semarang \\ Semarang, Indonesia \\ nursiyam@mail.unnes.ac.id
}

\begin{abstract}
Dengue Hemorrhagic Fever (DHF) is a major problem in Indonesia. In 2016, Incidence Rate (IR) = 77.96/100.000; Case Fatality Rate $($ CFR $)=0.79 \%$. Semarang City, the Capital of Central Java Province, is an endemic area of DHF. Gunungpati is a subdistrict that has a high incidence of DHF. Some health workers sell abate (temephos) without notifying the appropriate dosage. Long-term use of larvacide and inacurate dosage may lead to resistance. This study aimed to determine the resistance status of Aedes aegypti larvae to temephos in Gunungpati sub-district. The population study was all of Ae. aegypti larvae in Gunungpati sub-district and the sample was Ae. aegypti larvae trapped by ovitrap and reared by researcher to obtain the first generation (F1). F1 larvae would be randomly exposed to temephos, with doses according to the WHO guidelines. We counted larval death after 24 hours of exposure by larval resistance indicator. This was true experiment with randomized pretest-posttest design with control group. The results showed that Ae. aegypti larvae in Gunungpati sub-district were tolerant to temephos, because the average of larvae mortality were $81-95 \%$ in temephos exposure with WHO-recommended dose.
\end{abstract}

Keywords - resistance, Aedes aegypti, temephos.

\section{INTRODUCTION}

Dengue hemorrhagic fever (DHF) is still one of major health issues in Indonesia. The high incidence and distribution of this disease throughout Indonesia remain unsolved[1]. DHF outbreak often emerges in 5-10 years cycle. DHF is an infection of Dengue virus, which has four serotypes of flavivirus: DEN-1, DEN-2, DEN-3, DEN-4[2]. Those virus can be transmitted from female mosquito of Aedes aegypti, as the main vector, or from Aedes albopictus, as the secondary vector, to human[3].

One of the principal ways to control DHF is by breaking the chain of transmission and by controlling the DHF vector. Vector control has been considered more effective than simply treating the disease[4]. Larvae eradication is the strategic key of DHF vector control worldwide, because this can cut the life cycle of the mosquito[5]. The most prominent way to reduce the mosquito population in the community is by draining/tapping the water container/reservoir as well as brushing its wall, at least once a week. This treatment can prevent the larvae from growing into mosquito, therefore decreasing the population. Brushing the water reservoir wall tends to remove the eggs that stick to the wall. The eggs will drop, carried away by the draining water, and fail to hacth[6]. Insecticide use is an alternative way to diminish mosquito population. Chemical insecticide, such as larvacide, is commonly used in community to control the vector[7]. Abate or Temephos is the most common insecticide used in Indonesia. Temephos is one among a type insecticide that kill insect at larvae stage. Temephos preparation is mostly available as sand granules[8]. Temephos is pourable to any water reservoirs that are difficult to drain. The application dose of temephos is $1 \mathrm{ppm}$ or 1 gram for 10 litre of water[9].

For several decades, temephos was considered effective in preventing the larvae from evolving in water reservoirs. However, in the last several years, there were reports of its resistance in some countries, including Indonesia, such as in West Banjarmasin region that was in BanjarBaru, South Kalimantan. Some regions in Central Java, such as Tanjung Mas region of Semarang, Sidorejo subdisrict of Salatiga, and in Jakarta, such as Tanjung Priok and Mampang Prapatan, showed decreased sensitivity of Aedes Aegypti larvae toward temephos. The sensitivity tests toward temephos were conducted continuously in Dengue endemic regions[10]. The aim of the test was to determine the sensitivity status of Ae. Aegypti toward larvacide properties of temephos, because until present, temephos is still widely used to prevent the life cycle of Ae. aegypti.

There was no available data about resistance status of Ae. aegypti larvae in Gunungpati sub-district toward temephos $1 \%$, even though this region is endemic for DHF, mostly in the villages. This research aimed to obtain resistance status of Ae. aegypti larvae toward temephos $1 \%$. Temephos $1 \%(0,012 \mathrm{mg} / \mathrm{l})$ was the WHO-recommended dose. 


\section{MATERIALS AND METHODS}

This was an experimental study with Postest Only with Control Group Design. The sample of study was mosquito larvae of Ae.aegypti at instar III stage, from cultivation of first generation larvae obtained from Gunungpati subdistrict, Semarang city. In this study, the subject were divided in two group: the experiment group (receive temephos intervention at several different doses) and the control group (receive no intervention). The vulnerability test was conducted according to WHO conditions, using larvae instar III as the sample. The test initially used 25 larvae per cup for each treatment. Federer formula was used. According to Federer formula, 6 concentrations would needed at least four repetitions. The treatments (concentrations) given are temephos at concentration of: $0.003 \mathrm{mg} / \mathrm{l} ; 0.006 \mathrm{mg} / \mathrm{l} ; 0.012 \mathrm{mg} / \mathrm{l} ; 0.024 \mathrm{mg} / \mathrm{l} ; 0.048 \mathrm{mg} / \mathrm{l}$; and $0.096 \mathrm{mg} / \mathrm{l}$ with four repetitions. The larvae-temephos exposure was 24 hour. Total number of instar III needed was 700 larvae from each village.

Population in this study was first generation Ae. aegypti larvae (F1). Initially, the researchers trapped Ae. aegypti mosquito from environment while conducting survey in four villages of Gunungpati sub-district, Semarang City: village of Patemon, Sekaran, Mangunsari, dan Pakintelan. The selection of these 4 villages was based on the high annual incidence of DHF in these areas.

The Ae. aegypti larvae was collected using ovitrap. The placement of ovitrap was in several houses randomly. Then, we brought the trapped larvae to the laboratory for breeding. After they transformed into mosquitoes, they were placed in a special cage and were fed with blood and sugar water until they laid eggs. The eggs hatched first generation (F1) larvae. After turning into instar 3 larvae, we randomly selected them as sample.

Primary data collection was conducted by counting the number of the dead Ae. aegypti larvae in intervention group or control group. According to $\mathrm{WHO}$, resistance status of Ae. aegypti larvae was determined by the percentage dead larvae in $0.012 \mathrm{mg} / \mathrm{l}$ of temephos. The category of resistance status of Ae. aegypti toward temephos is as follow [4]:

1. Vulnerable/sensitive, if the larvae death was $98-100 \%$.

2. Tolerant, if the larvae death was $80-97 \%$.

3. Resistant, if the larvae death was $<80 \%$.

We use Anova to statistically test the difference between percentage of death of Ae. aegypti larvae in different temephos concentrations.

\section{RESULTS AND DISCUSSION}

This study described the region characteristic based on score of House Index (HI), Container Index (CI), Breteau Index (BI), and Angka Bebas Jentik (ABJ/Free Larvae Number). The number of exmined houses were 100 per villages.

According to Table 1, Sekaran village had the highest HI value (34\%) while Mangunsari village had the lowest HI value (16\%). Sekaran village also had the highest
CI value (30.2\%) while Mangunsari villlage had the lowest $(14.8 \%)$. The higher the value of $\mathrm{HI}$ and $\mathrm{CI}$ in the region, the higher the risk of DH transmission in the region[11]. Our data also showed that the vector existence in Gunungpati sub-district was fairly high. According Ministry of Health of Republic of Indonesia), ABJ lower than 95\% would increase the probability of dengue virus transmission.

Our findings also showed that Gunungpati subdistrict had regional high risk criteria for dengue transmission, because the average $\mathrm{HI}$ value in its 4 villages was $23.5 \%$, and the limit specified by government to reduce dengue incidence was $\mathrm{HI}>5 \%[12]$. HI value was one of most regular indicator to monitor the mosquitoes infestation level[13].

The CI value described the number of larvae-positive container, compared with all containers in the region. Hence, the CI value could describe the percentage of larvae positive container ${ }^{14}$. We obtained an average CI value of $20.75 \%$ in the 4 sample villages in Gunungpati sub-district of Semarang. Many rent houses or rooms for college students that was separated from the main house/building contributed for many larvae positive containers. The low awareness from the residents (college students) on draining water reservoirs regularly and on cleaning potential leftover bottles/glass that held water contributed for larvae positive containers.

TABLE 1. CHARACTERISTIC OF THE RESEARCH SitE

\begin{tabular}{|l|c|}
\hline \multicolumn{1}{|c|}{ Measurements } & Value \\
\hline Sekaran Village & \\
\hline Number of (+) larvae houses & 34 \\
\hline Numer of (+) larvae container & 41 \\
\hline Number of container examined & 136 \\
\hline HI & $34 \%$ \\
\hline CI & $30.2 \%$ \\
\hline BI & $41 \%$ \\
\hline ABJ & $66 \%$ \\
\hline Patemon Village & \\
\hline Number of (+) larvae houses & 21 \\
\hline Number of (+) larvae container & 21 \\
\hline Number of container examined & 113 \\
\hline HI & $21 \%$ \\
\hline CI & $18.6 \%$ \\
\hline BI & $21 \%$ \\
\hline ABJ & $79 \%$ \\
\hline Pakintelan Village & \\
\hline Number of (+) larvae houses & 23 \\
\hline Number of (+) larvae container & 25 \\
\hline Number of container examined & 129 \\
\hline HI & $23 \%$ \\
\hline CI & $19.4 \%$ \\
\hline BI & $25 \%$ \\
\hline ABJ & $77 \%$ \\
\hline Mangunsari Village & $16 \%$ \\
\hline Number of houses (+) larvae & $19 \%$ \\
\hline Numer of container (+) larvae & 19 \\
\hline Number of the examined container & 128 \\
\hline HI & $16 \%$ \\
\hline CI & \\
\hline BI & \\
\hline ABJ & \\
\hline & \\
\hline
\end{tabular}


They assumed that draining the water reservoirs was not a personal, collective responsibility. Therefore, they only relied on the other mates to do the job. This situation led the irregular draining of water reservoirs because only willing resident who do it. Mainly, mounting college tasks also limit their awareness because of lack time to clean the environment and to monitor mosquito larvae.

For the temephos usage, we did not directly observe whether the temephos application in Gunungpati was regularly or not. However, data from the interview showed that the community awareness was higher when DHF case was found in their area. It triggered them to use temephos to prevent the spread of the disease. Therefore, there was an irregular use of temephos in Gunungpati community. Based on interview, a staff of Puskesmas (Community health center) stated that Puskesmas staffs distributed free temephos for every family every time the DHF emerged in the region, or when there was request from the community. However, citizen revealed that beside the Puskesmas staffs/cadres, there were other people claiming as health worker and selling temephos.

TABLE II. PeRcentage Of LARVAe DeATH DifFERENCE IN SEVERAL TEMEPHOS CONCENTRATIONS

\begin{tabular}{|l|l|l|}
\hline \multirow{2}{*}{$\begin{array}{l}\text { Temephos } \\
\text { Concentration(mg/l) }\end{array}$} & \multicolumn{2}{|l|}{ Average Ae. aegypti Larvae Death } \\
\cline { 2 - 3 } Sekaran village & 14.5 & Percentage \\
\hline 0.003 & 18.75 & 58 \\
\hline 0.006 & 20.25 & 75 \\
\hline 0.012 & 24 & 81 \\
\hline 0.024 & 24.5 & 96 \\
\hline 0.048 & 25 & 98 \\
\hline 0.096 & 0 & 100 \\
\hline Control & \multicolumn{2}{|l|}{} \\
\hline Patemon village & 16.25 & 0 \\
\hline 0.003 & 19.25 & 65 \\
\hline 0.006 & 21.25 & 77 \\
\hline 0.012 & 23.25 & 85 \\
\hline 0.024 & 25 & 96 \\
\hline 0.048 & 25 & 100 \\
\hline 0.096 & 1 & 100 \\
\hline Control & \multicolumn{2}{|l|}{} \\
\hline Pakintelan village & 17.5 & 70 \\
\hline 0.003 & 19.5 & 78 \\
\hline 0.006 & 23.75 & 95 \\
\hline 0.012 & 25 & 100 \\
\hline 0.024 & 25 & 100 \\
\hline 0.048 & 25 & 100 \\
\hline 0.096 & 0 & 0 \\
\hline Control & 17 & 68 \\
\hline Mangunsari village & 19.5 & 78 \\
\hline 0.003 & 23.25 & 93 \\
\hline 0.006 & 24.5 & 98 \\
\hline 0.012 & 25 & 100 \\
\hline 0.024 & 25 & 100 \\
\hline 0.048 & 0 & 0 \\
\hline 0.096 & \multicolumn{2}{|l}{} \\
\hline Control & \multicolumn{2}{|l|}{} \\
\hline \multicolumn{4}{|l|}{} \\
\hline
\end{tabular}

During the study, we set the room temperature from initial intervention until the last intervention to $26-27^{\circ} \mathrm{C}$. Sudarto theory that declared that to reach optimum growth, the Ae. aegypti larvae needed optimum environment temperature between $25-30^{\circ} \mathrm{C}$. We could see this optimum growth in the control group where the percentage of larvae death was $<5 \%$.

The larva death was only due to exposure to temephos concentration, because the environment was well controlled. We measured the room humidity using hygrometer, and it measured about 64- 66\% from the beginning until the end of study. This condition fulfilled the examination standard for room humidity. The appropriate humidity promoted the life support of the mosquitoes from the eggs, larvae, pupas, until adults were $60 \%-80 \%$. Because the room temperature and humidity was favorable for the larvae lives, the larvae deaths should be due to nonenvironmental factor.

The percentage of larvae death at WHOrecommended dose of $0.012 \mathrm{mg} / \mathrm{l}$ indicated that there had not been reduced vulnerability status (resistant) toward the larvacide used (temephos $1 \%$ or Abate 1SG) in Ae.aegypti larvae in Gunungpati. However, because the average of the larvae death exposed with temephos $0.012 \mathrm{mg} / 1$ was $88.5 \%$, the larvae was considered tolerant. According to WHO criteria, larvae of Ae. aegypti reached the tolerant status when the percentage of death was $80-97 \%$. In this study, in Sekaran village, the percentage of larvae death at WHOrecommended dose showed only $81 \%$, Patemon village $85 \%$, Pakintelan village 95\%, and Mangunsari village 93\%. The use of temephos as one of larvacide compound was still applicable in larvae control in Gunungpati sub-district. However, due to the early tolerant status, larvacide rotation should be conducted in order to prevent the resistance. This result was unexpected considering temephos had been used for more than 20 years in Semarang City.

The tolerant status toward temephos in Gunungpati might be caused by the uncoordinated or unregulated use of this agent. Community that obtained temephos might have little knowledge in using it properly due to limited socialization. It is used also lacked monitoring and information on its appropriate and safe use of temephos. The acts of citizens to use the agent also affected the usage. Citizens lacking the knowledge on its roper use and its basic chemical properties increased the risk of resistance. Moreover, there were the Abate 1 SG distribution from some people claiming as health workers, leading to no valid record and monitoring from Puskesmas.

Larvacide used for larvae vector control in Gunungpati was Abate that contained active material of temephos $1 \%$ by pouring the agent granules in potential or difficult to drain water reservoirs.

The resistance status in Gunungpati sub-district was different from the other regions in Indonesia. North Banjarmasin and Banjarbaru of South Kalimantan, as well as some Regencies/Cities like South Kalimantan, Central Java, and Jakarta had susceptible status. The research of resistance status of Ae. aegypti larvae toward temephos tested by Bisset et al. in Cuba by studying Ae.aegypti larvae isolated from 15 locations di Havana City, resulted that all samples were resistant. Larvae of Ae. aegypti in endemic 
area in West Jakarta showed a tolerant and even resistant status to temephos[14].

From the resistance test, we found that there was percentage of larvae death of $<5 \%$ in the control group, especially in the larvae isolated from Patemon village. The death percentage in the control group (no temephos exposure) at the $24^{\text {th }}$ hour was $4 \%$, therefore the correction with Abbot's formula for control group was unnecessary.

Local health workers could consider preparing alternative larvacide to prevent temephos resistance in the area. In Gunungpati, the society had been trying several methods to control DHF disease. Among them are environmental management such as eradication of mosquito breeding ground (PSN) through the 3M Plus Program and sanitation management, although, there was still lack awareness from those who lived in boarding house.

Indication of resistance status to temephos was one of the method to regularly evaluate this insecticide effectiveness, so resistance could be detected and prevented[15, 16]. There was an awareness regarding cross resistance between $A e$. aegypti and temephos. It was possibly due to in managing DHF case in rainy season and the eradication of adult mosquitoes used fogging agent that also could promote resistance[17, 18]. The resistance of Ae. aegypti to temephos could also occur simultaneously with resistance to adulticida malathion or piretroid, complicating the vector control strategy[19].

Citizens in the village of Sekaran, Patemon, Pakintelan, and Mangunsari received free temephos from Puskesmas through PKK (Empowerment of Family Welfare) cadres in each region, particularly, during the rainy season when DHF incidence rise. But, there were also those who never received temephos from the cadres because of limited stocks of temephos. Beside, some of them bought temephos in the drugstore or from people that claiming as health workers.

\section{CONCLUSION}

Larvae of Ae. aegypti in Gunungpati sub-district, Semarang City, was tolerant toward temephos. The usage of temephos is still applicable in Gunungpati sub-district, Semarang city, but the rotation of larvacides is necessary to prevent further resistance.

\section{REFERENCES}

[1] J. Raharjo, "Themephos Effectiveness Test of Aedes aegypti larvae on Various Water Resources and Types of Water Reservoirs," Uji Efektivitas Themephos terhadap Larva Aedes aegypti pada Berbagai Sumber Air dan Jenis Bahan Tempat Penampungan Air. Loka Litbang P2B2 Banjarnegara, vol. 5(02), 2009, p. 12-16. http://ejournal.litbang.depkes.go.id/index.php/blb/article/view/1742/3 315.

[2] CDC, "Guideline for Evaluating Insecticide Resistance in Vectors Using the CDC Bottle Bioassay", CDC Methods, 2012, p. 1-28.

[3] S. Marcombe, F. Darriet, P. Agnew, M. Etienne, M. M. Yp-Tcha, A. Yébakima, et al, "Field efficacy of New Larvicide Products for Control of Multi-Resistant Aedes aegypti Populations in Martinique (French West Indies)," Am J. Trop Med Hyg, vol. 84(1), 2011, p. $118-126$.
[4] WHO, "Dengue Guidelines For Diagnosis, Treatment, Prevention and Control," in Prev Control, vol. 409(3), WHO Publication, 2009, p. 160.

[5] K. A. Polson, S. C. Rawlins, W. G. Brogdon, and D. D. Chadee, "Organophosphate Resistance in Trinidad and Tobago Strains of Aedes aegypti," J Am Mosq Control Assoc, vol. 26(4), 2010, p. 403410.

[6] S. C. Rawlins, and J. O. W, "Resistance in some Caribbean population of Aedes aegypti to Several Insecticides," J Am Mosq Control Assoc, vol. 11, 1995, p. 59-65.

[7] A. Ponlawat, J. G. Scott, and L. C. H, "Insecticide Susceptibility of Aedes aegypti and Aedes albopictus across Thailand," J Med Entomol, vl. 42. 2005, p. 821-5.

[8] S. H. P. P. Karunaratne, T. C. Weeraratne, M. D. B. Perera, and S. N. Surendran, "Insecticide Resistance and Efficacy of Space Spraying and Larviciding in The Control of Dengue Vectors Aedes aegypti and Aedes albopictus in Sri Lanka," Pestic Biochem Physiol, vol. 107(1), 2013, p. 98-105.

[9] S. S. Lasrika, Martini., L. D. Saraswati, "Status of Aedes aegypti (Linnaeus) larvae resistance to Temephos (Study in Jatiasih Village, Jatiasih Sub-District, Bekasi City, West Java Province)", Status Resistensi Larva Aedes aegypti (Linnaeus) terhadap Temephos (Studi di Kelurahan Jatiasih Kecamatan Jatiasih Kota Bekasi Provinsi Jawa Barat), Jurnal Kesehatan Masyarakat (e-Journal), vol. 4(1), 2016. https://ejournal3.undip.ac.id/index.php/jkm/article/view/11684/11342.

[10] S. R. Loke, W. A. A. Tan, S. Benjamin, H. L. Lee, and M. S. Azirum, "Susceptibility of Field-Collected Aedes aegypti (L.) (Diptera: Culicidae) to Bacillus thuringiensis israelensis and Temephos," Trop Biomed, vol. 27(3), 2010, p. 493-503.

[11] A. S. Joharina, "Larvae Density as an Indicator of Dengue Haemorrhagic Fever Transmision in Endemic Area in East Java" Kepadatan Larva Nyamuk Vektor sebagai Indikator Penularan Demam Berdarah Dengue di Daerah Endemis di Jawa Timur, Jurnal Vektor Penyakit, vol. 8(2), 2014, p. 33-40. http://ejournal.litbang.depkes.go.id/index.php/vektorp/article/view/36 $37 / 3584$.

[12] J. Zhu, "Mosquito Larvicidal Activity of Botanical-Based Mosquito Repellents," J Am Mosq Control Assoc, vol. 24(1), 2008, p. 161-8.

[13] L. Eisen, "Proactive Vector Control Strategies and Improved Monitoring and Evaluation Practices for Dengue Prevention," J Med Entomol, vol. 46(6), 2009, pp. 1245-1255.

[14] A. Gafur, and H. Mahrina, "The susceptibility of Aedes aegypti larvae from North Banjarmasin to Temephos", Kerentanan Larva Aedes aegypti dari Banjarmasin Utara terhadap Temephos. Bioscientiae, vol. 3(2), 2006, p. 73-82. file:///C:/Users/win10/Downloads/3967-5557-1SM.pdf.

[15] Felix, "When Larval and Adult Mosquitoes are Immune Against Insecticides", Ketika Larva dan Nyamuk Dewasa Sudah Kebal Terhadap Insektisida, Farmacia, 2008, vol. 7(7).

[16] Istiana, F. Heriyani, and Isnaini, "Resistance status of Aedes aegypti larvae to temephos in West Banjarmasin (Status of susceptibility of Aedes aegypti larvae to Temefos in West Banjarmasin)", Resistance status of Aedes aegypti larvae to temephos in West Banjarmasin (Status kerentanan larva Aedes aegypti terhadap Temefos di Banjarmasin Barat)," J Buski, vol. 4(2), 2012, p. 53-58. http://ejournal.litbang.depkes.go.id/index.php/buski/article/view/2916 $/ 2101$.

[17] J.B. Lima, P. da Cunha, Jr. Silva, A. K. Galardo, S. Soares, Braga, and R. P. D. V. Ramos, "Resistance of Aedes aegypti to Organophosphates in Several Municipalities in the State of Rio de Janeiro and Espirito Santo Brazil," Am.J Trop Med Hyg, vol. 68, 2003, p. 329-333.

[18] M. M. Rodriguez, J. Bisset, D. M. deFernandez, and L. A. S. Lauzan, "Detetion of Insecticide Resistance in Aedes aegypti (Diptera: Culicidae) from Cuba and Venezuela," J Med Entomol, vol. 38, 2001, pp. 623-628.

[19] A. B. Failloux, A. Ung. And M. N. P. Raymond. "Insecticide Susceptibility Inmosquitoes (Diptera: Culicidae) from French Polynesia," J Med Entomol, vol. 31, 1994, p. 639-644. 